\title{
Energy efficiency and low-carbon technologies in urban renewal
}

\author{
Minna Sunikka
}

OTB Research Institute for Housing, Urban and Mobility Studies, Delft University of Technology, Jaffalaan 9, NL-2628 BX Delft, the Netherlands E-mail: M.Sunikka@otb.tudelft.nl

\begin{abstract}
Buildings belong to the most cost-effective sectors where carbon dioxide $\left(\mathrm{CO}_{2}\right)$ reductions can be achieved, and urban regeneration offers a good intervention point for switching to sustainable fuel sources, as changes in energy infrastructure can be coupled with other construction, thus decreasing the cost. However, the potential energy savings that are feasible do not match the more ambitious policy targets. Based on case studies in the Netherlands, obstacles are identified in the context of urban renewal that need to be overcome if energy efficiency measures are to be implemented and space heating replaced with low-carbon technologies. The current free-market public policy instruments have not managed to address the obstacles identified in the case studies due to poor market signals, costs and payback periods, risks, and a lack of leadership on environmental targets and policies on sustainable urban renewal. The potential for stronger government intervention is examined for the effectiveness in reducing both energy consumption and $\mathrm{CO}_{2}$ generation. Legislation could produce a certain policy outcome in terms of $\mathrm{CO}_{2}$ reduction in urban renewal in the Netherlands if compliance and legitimacy are ensured, but policy consideration is also required to account for the dilemma of lowincome households and the rebound effects associated with occupant behaviours.
\end{abstract}

Keywords: building stock, carbon reduction, energy efficiency, housing, public policy, renovation, urban renewal, the Netherlands

Les bâtiments appartiennent à l'un des secteurs les plus rentables où il est possible de réaliser des réductions de $\mathrm{CO}_{2}$ et où la rénovation urbaine permet de passer à des sources de combustibles durables, les modifications apportées aux infrastructures énergétiques pouvant être couplées avec d'autres constructions, ce qui en diminue le coût. Toutefois, les économies qu'il est possible de réaliser au niveau de l'énergie ne correspondent pas aux objectifs politiques plus ambitieux. Des études de cas menées aux Pays-Bas ont permis d'identifier, dans le contexte du renouveau urbain, des obstacles qu'il faut surmonter si l'on veut mettre en œuvre des mesures d'efficacité énergétique et si l'on veut remplacer le mode actuel de chauffage des locaux par des technologies à faible dégagement de $\mathrm{CO}_{2}$. Jusqu'à présent, les instruments de la politique publique libérale n'ont pas permis de renverser ces obstacles pour les raisons suivantes: faibles signaux du marché, coûts et périodes de récupération, risques et manque de leadership en matière d'objectifs environnementaux et de politique concernant la rénovation urbaine durable. Cet article examine les possibilités d'un interventionnisme plus fort de la part des autorités pour améliorer la réduction à la fois de la consommation d'énergie et de la production de $\mathrm{CO}_{2}$. La législation pourrait produire quelques résultats en termes de réduction du $\mathrm{CO}_{2}$ dans la rénovation urbaine aux Pays-Bas si l'on garantit la compatibilité et la légitimité; mais il faut également prendre en considération les questions de politique et tenir compte de l'impasse que constituent les foyers à faibles revenus et les effets de rebond associés au comportement des occupants.

Mots clés: patrimoine immobilier, réduction de $\mathrm{CO}_{2}$, efficacité énergétique, logements, politique publique, rénovation, rénovation urbaine, Pays-Bas 


\section{Introduction}

Improving energy efficiency in existing buildings is often considered to be one of the most cost-effective measures for cutting down on carbon emissions (Ashford, 1999; Lowe, 2000; Van der Waals, 2001) and considerable energy saving potential has been demonstrated in different countries (Hekkanen et al., 1999; Badescu and Sicre, 2003; Hastings, 2004; European Commission, 2005). Urban renewal provides a good intervention point for energy improvements as they can be coupled with other renovation measures and provides synergy when performed together (Kohler and Hassler, 2002). Both physical and economic neighbourhood renewal is essential to ensure that investments in energy efficiency pay off, as the value of a building depends not only on the quality of the building itself, but also on that of the surrounding buildings, the infrastructure and the neighbourhood. Consequently, urban renewal provides an incentive to spend more on improving building quality (Awano, 2005).

Energy efficiency and the use of renewable sources in the construction sector could also contribute to selfsufficiency and solving peak demand and stand-by capacity problems (Sinden, 2005). Urban environment policy, however, has yet to deal with the issue of carbon dioxide $\left(\mathrm{CO}_{2}\right)$ (Priemus, 1999) and the environment continues to play only a small part in urban regeneration projects, e.g. in the Netherlands (Bus, 2001; Priemus, 2002). Initial capital costs are emphasized over life cycle costs (Jones et al., 2002), and cost is often seen as the main barrier to adopting carbon reduction measures in urban regeneration, but this concern is based on a face value impression of cost rather than any consideration of the actual costs and benefits (Van der Waals et al., 2003).

In the Netherlands, the government has set a target of reducing $\mathrm{CO}_{2}$ emissions from the existing building stock by 3 million tonnes (Mt) by 2010 compared with the 'business-as-usual' trend (Ministry of Spatial Planning, Housing and the Environment (MVROM), 1999). If the market worked effectively and with the right cost-benefit ratio, the monetary value of energy efficiency measures would be reflected in the resale value of homes (Clinch and Healy, 1999), but there seems to be insufficient market demand for sustainable building measures (Stichting Bouwresearch, 2001; Baumann et al., 2002). A significant proportion of policy instruments for reducing $\mathrm{CO}_{2}$ emissions still target new buildings, while government bodies have done little to upgrade existing buildings (Sunikka, 2001; Hasegawa, 2002; Murakami et al., 2002; Sunikka and Boon, 2003; Boardman, 2004b; Awano, 2005). The policies for the existing buildings that exist seem to be formulated with little reference to specific needs, instead of making precise estimations and basing policy measures on detailed sets of requirements and costs (NOVEM, 2002; PRC (Bouwcentrum International), 2005).

The aim of the present study is twofold. First, based on two case studies in the Netherlands, it aims to describe the benefits and obstacles when implementing energy efficiency improvements in existing housing and using sustainable energy sources in urban renewal. The first case study focuses on the following question. What is the economically feasible energy-saving potential from renovating post-war housing? The second case study addresses the following question. What are the obstacles to replacing gas-fired heating with low- and zero-carbon technologies as part of urban regeneration? Second, as the concept of sustainable development used in this research is the institutional one, sustainability is considered as being essentially a problem of governance in the broadest sense (Perman et al., 2003), and the present paper discusses policy instruments for an effective policy to overcome the obstacles. Policy recommendations focus on the following question. To what extent is stronger government intervention needed to circumnavigate the barriers, and what policy approach would be effective to improve energy efficiency in the existing housing stock?

\section{Research method}

Case studies can be used for explorative, descriptive, explanatory or illustrative research (Yin, 1993). The present study was based on an explorative approach, looking at the feasibility of policy targets in practice. The case studies were taken from the Netherlands because since the mid-1980s the country has emerged as an international leader in the environmental field, it has a tradition of effective planning (Cohen, 2000) and an established sustainable building policy (Sunikka, 2001). The projects were selected on the basis of two criteria: they had to involve a late postwar residential district where most of the regeneration operations would be carried out, and they had to include some aspirations and objectives regarding sustainable building.

The 'trias energetica' approach was adopted in the case studies because it is a generally recognized concept in the Netherlands. It sets out three steps to achieving sustainable energy consumption: avoiding unnecessary energy consumption, using non-finite sources, and adopting a clean and efficient use of finite sources (Duijvestein, 1998). The first case study (Hoogvliet, Rotterdam) focused on the first step, avoiding unnecessary energy consumption. The first case study entailed carrying out energy evaluations of the various renovation solutions using the Energy Performance Advice (EPA) tool, a widely used voluntary method of energy evaluation in the Netherlands. 
The EPA consists of a collection of input data from a survey of the location, which include building characteristics, heating, hot water, and electricity consumption of pumps and fans, an assessment of the Energy Index and energy-saving measures, advice and a digital EPA report and monitoring of data (Beerepoot and Sunikka, 2005). Energy savings are based on delivered energy ( $\mathrm{m}^{3}$ gas and $\mathrm{kWh}$ electricity) and presented in terms of carbon. The life expectancy of the buildings was 25 years before the next intervention; that of the installations was 15 years before the next intervention. The cycle of 25 years was proposed by the housing associations that participated in the research project so the renovation was assumed to take place once and not enhanced before the next intervention, despite the price scenarios. Furthermore, gas prices for average households in the Netherlands have increased from $€ 0.29$ to $€ 0.40$ per $\mathrm{m}^{3}$ between 1999 and 2003, including value added tax (VAT) (an average annual increase $14 \%$ ) but this has not generated large-scale investments in energy efficiency in the housing stock. The measures to improve the energy performance of a dwelling presented in this study are incremental, low-cost improvements, focusing on dwelling-related energy consumption, i.e. the consumption influenced by the technical condition of the home, comprising natural gas consumption and part of electricity consumption. The energy used for domestic appliances is beyond the scope of this study. The environmental impact of existing housing was focused on energy efficiency as distinct from energy conservation, which was understood to result from behavioural changes (Boardman, 2004a). However, it was recognized that technical solutions can contribute only a small amount to reducing environmental impact and changing the occupant behaviour is necessary.

It is extremely rare that what is deemed desirable is also feasible in terms of time and money (Van der Voordt and Van Wegen, 2002). The commercial viability of a project was assessed using the net present value (NPV) test, which gives the present value of the net cash flow associated with it. The NPV was conducted from the point of view of the investor: the housing association. The decision rule was to proceed with the project only if NPV $\geq 0$. The investment level was set low, as similar renovation measures were to be carried out in more than 50 dwellings. These can be criticized as being relatively simple methods of ascertaining financial viability, but they are transparent and adequate when it comes to pointing out the main factors in environmental investment in real estate. All costs were calculated excluding VAT. The investment costs were calculated without subsidy, as government energy subsidies in the Netherlands were abolished in 2003 . The gas price used was $€ 0.367$ per $\mathrm{m}^{3}$, including the regulatory energy tax (REB). The gas price in the Netherlands is commonly expressed as euros per $\mathrm{m}^{3}$.
Cubic meters of natural gas can be converted to $\mathrm{kWh}$ or megajoules (MJ) so that $1 \mathrm{~m}^{3}=9.8 \mathrm{kWh}$ or $35.17 \mathrm{MJ}\left(1 \mathrm{~m}^{3}=35.31\right.$ cubic feet $)$, so that the gas price used was $€ 0.037$ per $\mathrm{kWh}$ or $€ 0.010$ per MJ. The electricity price used was $€ 0.128$ per $\mathrm{kWh}$, including the REB. The costs were based on an inflation rate of $2.9 \%$ and an interest rate of $6.5 \%$. Although forecasting entails obvious risks and is complicated by the difficulty of predicting innovations in building products, a number of energy price scenarios were used as a background against which to examine the results.

The second case study (Western Garden Cities, Amsterdam) focused on the second step of the 'trias energetica' approach, using non-finite sources to provide heat and electricity. This case study was qualitative and focused on the processes. Analysis was based on the key policy documents and interviews among those related with the project.

In this paper, urban renewal is defined as creating conditions for improving the quality of housing, work, production, and the environment in and around the cities by taking measures aimed at the spatial management of the residential environment. It is mostly a physical intervention with the purpose of upgrading a whole neighbourhood, where renewal of housing is supplemented with an improvement of open spaces, traffic regulation and better urban infrastructure (Skifter Andersen and Leather, 1999). The literature provides few definitions for sustainable urban renewal but Bus (2001) defines it as a district-based approach geared to solving existing problems, preventing new problems, improving the quality of local environment and reducing supra-local environmental pollution. Renovation was chosen as the main renewal strategy because renovation-based interventions in the housing stock would appear to be better options from the environmental point of view than consolidation or new build (De Jonge, 2005; Klunder, 2005). In terms of type of tenure, the present study focuses on the social housing sector, because in $2000,36 \%$ of all housing in the Netherlands was social housing (Kruythoff and Haars, 2002), and since it is mostly concentrated on urban renewal areas, housing associations have a very central role in the renewal process (Ouwehand and Van Daalen, 2002).

Research was conducted in the framework of the Habiforum programme 'Innovative Land Use' (BSIK), which is an expert network promoting innovations in spatial planning with government funding in the Netherlands, and Corpovenista (Housing Associations Renewing the City, a project running in 2004-07), which is a joint venture of Aedes (the branch organization of Dutch housing associations), a number of Dutch housing associations, the Dutch government and Stichting Bouwresearch (SBR). 


\section{Case study 1: Energy efficiency improvements in the renovation of post-war housing \\ Hoogvliet, Rotterdam, the Netherlands}

The area covered by the first case study is Hoogvliet in the Municipality of Rotterdam, part of the Meeuwenplaat housing estate, which consists of around 3000 dwellings located in similar five-storey blocks built in 1959 (Figure 1). About 76\% of the dwellings are social rented housing, mainly in the lowest rent bands. The case study looked at 26 dwellings with an average surface area of about $60 \mathrm{~m}^{2}$. The exterior walls are of cavity construction. Double glazing and external wall insulation $(50 \mathrm{~mm})$ were installed in some parts of the facade in an earlier renovation. The floor and loft are not insulated. The energy demand is dominated by the use of natural gas for space heating. Gas is also used for domestic hot water and cooking, and electricity is used for other energy services. The building has natural ventilation. The internal staircase and most of the ground floor are unheated. The dwellings are heated by individual gasfired systems and domestic hot water is provided by an instantaneous heater in the kitchen. The annual average indoor temperature was around $15^{\circ} \mathrm{C}$. This is not the actual temperature in all rooms but the average temperature of the whole apartment over 24 hours. It is relatively low because bedrooms, for example, are not heated during the day in the Netherlands and in other spaces such as kitchens the heating is turned off during the night so the temperature can drop low.

The Hoogvliet regeneration project involves demolishing $33 \%$ of the total building stock between 1999 and 2020, including all housing in the case study. The decision to demolish and build new homes rather than renovate is based on the market value of and demand for new dwellings, which is much higher

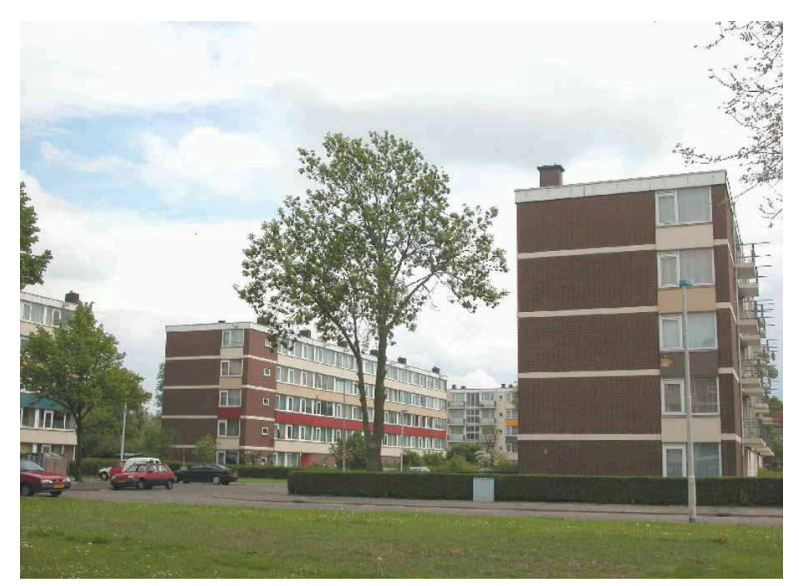

Figure 1 Case study 1: Hoogvliet, Rotterdam, the Netherlands. Source: author than that of a renovated post-war block of flats in most cases. The study was conducted to recognize the energy-saving potential in housing renovation.

\section{Analysis}

Four renovation solutions to improve energy efficiency were examined in the first case study using the EPA tool, which is based on the National Package for Sustainable Management, a widely used collection of standard environmental measures in the Netherlands (Stichting Bouwresearch, 1998a, b). Solution 1 entailed improving the building's thermal performance by adding cavity wall, loft and floor insulation to the thermal envelope. Solution 2 involved installing new extra-high-performance windows in addition to the insulation. Solution 3 added an HR107 boiler for space heating and a heat pump boiler for domestic hot water, with water-saving equipment, to solution 2. The high-efficiency boiler is installed in each flat. HR107 is a label for the most energy efficient condensing boilers has a minimum $107 \%$ efficiency factor, considering the heat released in condensation. Solution 4 looked at installing a solar boiler in addition to the previous measures. Collective solar panels are installed on the roof of each building and each flat has its own solar boiler. The installation of a solar boiler is considered to reduce the demand for natural gas with $150-200 \mathrm{~m}^{3}$ in an average household in the Netherlands. The reference level was the current situation of standard maintenance without any environmental measures. The energy evaluation in the case study, looking at one building, is shown in Table 1 .

The case studies show that there is a potential for carbon reduction at an operational level in existing housing. Solution 2 resulted in a $\mathrm{CO}_{2}$ reduction of 40 $327 \mathrm{~kg}$ and a $44 \%$ reduction in total gas consumption; in terms of the total energy costs, the saving was $€ 7082$ (€272 per average dwelling per year). Solution 4 reduced gas consumption by $79 \%$ at the current level, although there was a slight increase in electricity consumption, and $\mathrm{CO}_{2}$ emissions were reduced by 48 $177 \mathrm{~kg}$, resulting in an annual cut in energy costs of $€ 6737$ ( $€ 259$ per average dwelling per year). The $\mathrm{CO}_{2}$ reduction required a relatively high investment: solution 2 costs $€ 168235$ (€6471 per average dwelling), and solution $4 € 368046$ (€14 156 per average dwelling). If one compares these results with a standard renovation (a zero option where building components and systems are replaced like with like), the additional expenditure was $€ 119654$ for solution 2 and $€ 304161$ for solution 4 . Solution 2 would seem to be the most cost-effective measure in the case study as regards cutting $\mathrm{CO}_{2}$ emissions: compared with a standard renovation, it could produce $70 \%$ more $\mathrm{CO}_{2}$ reduction and save $38 \%$ more in total energy costs for an additional $29 \%$ investment. Similar results were obtained in two similar case studies 
Table 1 Energy evaluation in the case study

\begin{tabular}{|c|c|c|c|c|c|}
\hline \multirow[t]{2}{*}{ Options } & Reference & Solution 1 & Solution 2 & Solution 3 & Solution 4 \\
\hline & $\begin{array}{l}\text { Existing } \\
\text { situation }\end{array}$ & Insulation & $\begin{array}{l}\text { Solution } 1+ \\
\text { widows }\end{array}$ & $\begin{array}{l}\text { Solution } 2+ \\
\text { installations }\end{array}$ & $\begin{array}{l}\text { Solution } 3+ \\
\text { solar boiler }\end{array}$ \\
\hline Energy index & 1.13 & 0.86 & 0.78 & 0.74 & 0.66 \\
\hline Space heating ( $\mathrm{m}^{3}$ gas) & 28000 & 13145 & 9332 & 9370 & 9370 \\
\hline Tap water heating ( $\mathrm{m}^{3}$ gas) & 15087 & 15260 & 15260 & 0 & 0 \\
\hline Total gas consumption $\left(\mathrm{m}^{3}\right)$ & 43887 & 28405 & 24592 & 9370 & 9370 \\
\hline Gas savings $\left(\mathrm{m}^{3}\right)$ & - & 15482 & 19295 & 34517 & 34517 \\
\hline Tap water heating (kWh) & 0 & 0 & 0 & 61184 & 41608 \\
\hline Ancillary energy (kWh) & 7929 & 7929 & 7929 & 11091 & 12591 \\
\hline Lighting (kWh) & 9181 & 9181 & 9181 & 9181 & 9181 \\
\hline Total electricity consumption (kWh) & 17111 & 17111 & 17111 & 81456 & 63380 \\
\hline Electricity savings (kWh) & - & 0 & 0 & -64345 & -46270 \\
\hline Expenditure (excluding subsidies and VAT) (€) & - & 108179 & 168235 & 322404 & 368046 \\
\hline $\begin{array}{l}\text { Extra expenditure (excluding } \\
\text { subsidies and VAT) }(€)\end{array}$ & - & 85263 & 119654 & 258519 & 304161 \\
\hline Gas costs (excluding VAT) $(€)$ & 16107 & 10425 & 9025 & 3439 & 3439 \\
\hline Electricity costs (excluding VAT) (€) & 2194 & 2194 & 2194 & 10443 & 8125 \\
\hline Annual receipts in total energy costs $(€)$ & - & 5682 & 7082 & 4419 & 6737 \\
\hline Payback time (years) & - & 30 & 45 & - & - \\
\hline Payback time extra investments (years) & - & 21 & 25 & - & - \\
\hline $\mathrm{CO}_{2}$ emission reduction $(\mathrm{kg})$ & - & 31641 & 40327 & 39562 & 48177 \\
\hline MJ gas for EPL calculations & 1721614 & 1096444 & 924809 & 390498 & 390498 \\
\hline MJ electricity for EPL calculations & 157945 & 157945 & 157945 & 611444 & 470943 \\
\hline Change in the reference energy index (\%) & - & 24 & 31 & 35 & 42 \\
\hline
\end{tabular}

Note: EPL, energy performance per location. VAT, value added tax. Source: author.

conducted as part of the research project (Boon and Sunikka, 2004).

A general rule is that only investments with a positive NPV should be made: Table 2 thus relates the cumulative returns from the various renovation solutions to the additional costs. Solutions 1 and 2 will have a positive NPV after around 20 years from the investment, but the NPVs of solutions 3 and 4 will remain negative after 25 years, at the time of the next intervention.

Energy prices are expected to rise because of regulatory measures, government action, the implementation of the Kyoto treaty, a more dynamic energy market, the pressure to satisfy electricity demand with zeroemission technology and taxes.

Table 3 shows the NPVs for the renovation solutions after 25 years based on additional expenditure in relation to three different price scenarios (Jansen et al., 2003). Scenario A is based on the current trend in energy prices with a $2.9 \%$ inflation rate. Scenario $\mathrm{B}$ is based on the assumption that energy prices will gradually rise by $30 \%$ by 2012 compared with the level in 2003 and that the Kyoto Protocol will not be implemented. Scenario C is based on the prediction that the Kyoto Protocol will be implemented, causing a real $60 \%$ rise in energy prices by 2012 compared

Table 2 Net present values (NPV) of the various investment options for additional expenditure compared with standard renovation, after 25 years

\begin{tabular}{lllc}
\hline Options & Solution 1 & Solution 2 & Solution 3 \\
\cline { 2 - 4 } & Insulation & $\begin{array}{l}\text { Solution 1 plus } \\
\text { windows }\end{array}$ & $\begin{array}{l}\text { Solution 2 plus } \\
\text { installations }\end{array}$ \\
\hline $\begin{array}{l}\text { Extra expenditure compare with } \\
\text { standard renovation }(€)\end{array}$ & 85263 & 119654 & $655457^{1}$ \\
$\begin{array}{c}\text { Cumulative receipts in energy costs } \\
\text { after 25 years NPV }(€)\end{array}$ & 98802 & 123146 & 76840 \\
$\begin{array}{l}\text { NPVafter 25 years }(€) \\
\text { s.lar boiler }\end{array}$ & 13539 & 3492 & -578617 \\
\hline
\end{tabular}

Note: ${ }^{1}$ Since the life cycle of installations is 15 years, the investment needs to be made twice during the 25 -year life cycle of the dwelling. The second investment takes account of an inflation rate of $2.9 \%$.

Source: author. 
Table 3 Net present values (NPV) of the various investment options compared with standard renovation in the case of (A), the current trend in energy prices; (B) an expected 30\% increase in energy prices in 2012 compared with 2003 (without Kyoto); and (C) a 60\% increase in 2012 compared with 2003 (with Kyoto)

\begin{tabular}{|c|c|c|c|c|c|}
\hline \multirow[t]{2}{*}{ Options } & Standard & Solution 1 & Solution 2 & Solution 3 & Solution 4 \\
\hline & $\begin{array}{l}\text { Standard } \\
\text { renovation }\end{array}$ & Insulation & $\begin{array}{l}\text { Solution } 1 \text { plus } \\
\text { windows }\end{array}$ & $\begin{array}{l}\text { Solution } 2 \text { plus } \\
\text { installations }\end{array}$ & $\begin{array}{l}\text { Solution } 3 \text { plus } \\
\text { solar boiler }\end{array}$ \\
\hline $\begin{array}{l}\text { Extra expenditure compared with standard } \\
\quad \text { renovation }(€)\end{array}$ & 0 & 85263 & 119654 & $655457^{1}$ & $771180^{1}$ \\
\hline Annual receipts in energy costs $(€)$ & 160 & 5682 & 7082 & 4419 & 6737 \\
\hline \multicolumn{6}{|l|}{ (A) Current energy price } \\
\hline $\begin{array}{l}\text { Cumulative receipts in energy costs after } 25 \\
\text { years NPV }(€)\end{array}$ & 2782 & 98802 & 123146 & 76840 & 117147 \\
\hline NPV after 25 years $(€)$ & - & 13539 & 3492 & -578617 & -654033 \\
\hline \multicolumn{6}{|l|}{ (B) $+30 \%$ increase in 2012 (without Kyoto) } \\
\hline $\begin{array}{l}\text { Cumulative receipts in energy costs after } 25 \\
\text { years NPV }(€)\end{array}$ & 3951 & 140321 & 174895 & 109130 & 166375 \\
\hline NPV after 25 years $(€)$ & - & 108179 & 55241 & -546327 & -604805 \\
\hline \multicolumn{6}{|l|}{ (C) $+60 \%$ increase in 2012 (with Kyoto) } \\
\hline $\begin{array}{l}\text { Cumulative receipts in energy costs after } 25 \\
\text { years NPV }(€)\end{array}$ & 5790 & 205600 & 256258 & 159899 & 243774 \\
\hline NPV after 25 years $(€)$ & - & 120337 & 136604 & -495558 & -527406 \\
\hline
\end{tabular}

Note: ${ }^{1}$ Since the life cycle of installations is 15 years, the investment needs to be made twice during the 25 -year life cycle of the dwelling. The second investment takes account of an inflation rate of $2.9 \%$.

Source: author.

with 2003 (corrected for inflation). The results show that if energy prices increase by $30 \%$ by 2012 , the NPV for solutions 1 and 2 will become positive around 16 and 18 years from the investment, respectively. If prices increased by $60 \%$ by 2012 , as anticipated in the Kyoto Protocol (Jansen et al., 2003), the NPV will be positive around 13 and 14 years, respectively, but the NPV for solutions 3 and 4 will still remain negative after 25 years. There are various funding options and public-private partnerships (PPPs) available, but the question is who will be willing to take on the investment if the NPV of the energy improvements remains negative?

\section{Case study 2: Energy supply using low- carbon technologies in urban renewal Western Garden Cities, Amsterdam}

This case study looked at the Western Garden Cities in Amsterdam to see what barriers there are to replacing gas-fired heating with low- and zero-carbon technologies as part of urban renewal. The Western Garden Cities area consists of a number of neighbourhoodsSlotermeer, Slotervaart, Geuzenveld, Osdorp and Overtoomse Veld-built after the war on the western outskirts of Amsterdam (Figure 2). It has around 130 000 people living in 54000 dwellings, 10000 of which are to be demolished as part of the regeneration of the area and replaced by 17500 new homes by 2015 . The energy demand is dominated by the use of natural gas for space heating. Gas is also used for domestic hot water and cooking, and electricity is used for other energy services. There are substantial opportunities for energy saving in these homes, as many of them date back over 40 years and have major heat losses. Previous studies and policy documents estimated that a $34-49 \% \mathrm{CO}_{2}$ reduction is feasible as part of the renewal of the Western Garden Cities (Ligthart et al., 2000; Bureau Parkstad, 2001). Half of this reduction would come from improvements in building technology, such as insulation, the other half from a largescale energy supply.

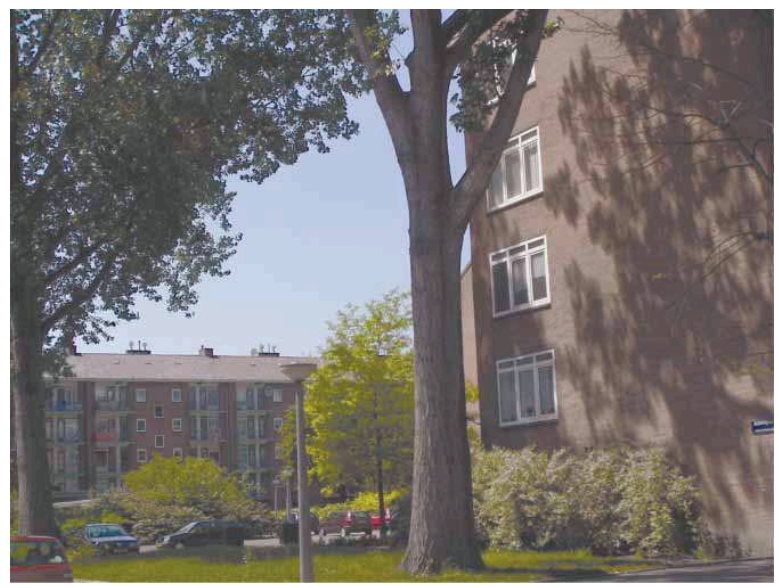

Figure 2 Case study 2: Western Garden Cities, Amsterdam, the Netherlands. Source: author 


\section{Analysis}

Table 4 summarizes a number of low- and zero-carbon technologies. Not all these sources are suitable for urban renewal, however: biomass boilers are likely to remain a special solution for rural areas; wind in urban areas is unpredictable and causes a nuisance; and heat pumps are likely to be limited to new build because installing them in existing buildings requires major internal changes. A smaller-scale alternative for heat and electricity supply is micro-CHP, i.e. domestic combined heat and power. This involves the simultaneous production of heat and power in a single building, using small energy-conversion units where the heat produced is used for space and water heating (and possibly for cooling), and the electricity is used within the building or fed into the grid. Various conversion technologies have been developed for domestic applications, e.g. reciprocating engines, Stirling engines, low- and high-temperature fuel cells, and micro-gas turbines, and these are slowly coming onto the market. So far, micro-CHP systems have relied mainly on natural gas, making them a 'grey' rather than a 'green' energy supply, but they do reduce greenhouse gas emissions and resource consumption compared with the average energy supply. Solar energy systems, like most current renewable technologies, struggle to pay back during their lifetime, but their current cost-effectiveness is by no means a guide to what it could be in the future. Renewable energy sources are expected to develop greatly during the next few decades. In the UK, for example, it is thought that solar water heating will be installed in around two-thirds of homes by 2050, and the cost of photovoltaic cells is commonly estimated to halve every 10 years (Boardman et al., 2005).

A feasibility study of the measures required to achieve the $50 \% \mathrm{CO}_{2}$ reduction target in the Western Garden Cities concluded that an energy supply with district heating appeared to be the best way of achieving the target (W/E Adviseurs, 2002). District heating using waste heat from the Afval Energie Centrale (AEC) in the Western Docks Area was finally identified as being economically feasible. Three energy providers were asked to make an offer, and Essent's heat distribution offer was chosen on the grounds that it had the most affordable price. Another offer, based on the use of solar energy, would have been more costly. Later on in the process, however, Essent was not able to meet the requirements, and negotiations began with the Afval Energiebedrijf (AEB). In 2004, the housing estates, municipality and most of the housing associations took the decision to proceed with the new energy grid for new-build homes and major renovations. The network is to be implemented and run by Westpoort Warmte BV (WPW), a joint venture of the AEB and Nuon Warmte. Switching from gas to district heating, provided by industrial waste heat, in 25000 dwellings in the Western Garden Cities could contribute an annual $\mathrm{CO}_{2}$ reduction of 34 million $\mathrm{kg}$ a year to the city of Amsterdam. It would be the largest heating project in the Netherlands. If a new energy infrastructure is implemented only in new buildwhich has a lower energy consumption than the existing stock in any case-the carbon reduction is very limited. This option, however, is probably the one that will be adopted.

It should be noted that when a new energy infrastructure is implemented, the carbon saving achieved through district heating is not immediate, as the distribution network takes time to be built and existing homes need to be adapted internally to the new energy system. Replacing the gas network with a new energy distribution network requires kilometres of underground structures. These are usually hidden under existing roads, but constructing them causes a nuisance to residents and damage to trees and other vegetation. Under the current plan, from 2005, clusters of housing in the Western Garden Cities will have temporary boilers while the final infrastructure is being built: these also increase the cost of implementation, and the long implementation period makes for greater risk. The energy infrastructure will be completed in 2009-11, when all the homes will be connected to the AEC network and the temporary boilers

Table 4 Sustainable energy sources

\begin{tabular}{|c|c|c|c|}
\hline & Heat only & $\begin{array}{l}\text { Heat and } \\
\text { electricity }\end{array}$ & Electricity only \\
\hline Low carbon & Heat pumps & $\begin{array}{l}\text { Gas-fired CHP for district heating } \\
\text { Gas-fired micro-CHP (Stirling engine) } \\
\text { Gas-fired micro-CHP (fuel cells) }\end{array}$ & - \\
\hline $\begin{array}{l}\text { Zero net } \\
\text { carbon }\end{array}$ & $\begin{array}{l}\text { Solar hot water } \\
\text { Biomass Geothermal }\end{array}$ & $\begin{array}{l}\text { Energy from waste or biomass CHP } \\
\text { for district heating } \\
\text { Biomass in micro-CHP (e.g. Stirling engines) }\end{array}$ & Photovoltaics Wind \\
\hline
\end{tabular}


will be removed. In 2011, most homes in the Western Garden Cities will obtain $100 \%$ of their heating from the AEC (cost is the limiting factor that prevents $100 \%$ connection to the grid sooner). The carbon reduction will therefore also begin with a delay, but the energy-saving target should be feasible in the longer-term.

District heating was chosen mainly because it would not cause additional costs to the municipality, housing associations or residents. The feasibility of the AEC energy supply is limited by cost, however. EnergieNed, the federation of energy companies in the Netherlands, lays down a maximum annual tariff to consumers for gas in the Netherlands $(€ 17.15$ per GJ excluding VAT, or $€ 187.33$ per dwelling, in 2003), which must not be exceeded regardless of the energy source. This 'no more than otherwise' (NietMeer-dan-Anders, NMDA) principle applies to the Western Garden Cities. A third party makes the investment required in a sustainable energy source instead of the residents, but the residents pay the same price for the energy they consume as if it came from conventional sources, regardless of whether the residents consume less energy, in order to pay back the investment. The NMDA principle is one option to tackle the capture of benefits, but it can have unwanted side-effects as residents do not receive any feedback on their energy consumption.

There are also a number of risks related to future energy prices: the energy market and inflation, the final cost of the new energy infrastructure, the remodelling of streets and open spaces, estimating the right number of dwellings to be connected to the network, the construction rate, and the actual cost of installation. The liberalization of the energy market has produced commercial energy companies that are more interested in market factors and less in the environment.

Current renewal projects in the Netherlands are often administered by policy networks rather than by regional government, as is the case in the Western Garden Cities. The introduction of a bigger role for the market mechanism in urban renewal in the national report on housing in 1989 was an important move in the direction of a property-led approach to urban renewal (Verhage, 2005), followed by the operation in 1995 through which the housing associations were made financially independent from the central government, making the risk and reward aspect of renewal projects more important for them. Responsibilities are consequently divided up among a large number of organizations: the energy supplier (the plant), the energy distributor, several departments of the municipal authority, four neighbourhoods, ten to 12 housing associations which play an important role in regeneration, and the residents, each with their own interests and economic position, even their own concepts of sustainability. Less governance seems to have both positive and negative effects: on the positive side, it has produced more flexibility, but it seems also to have led to fragmentation in policy implementation, with no priority being given to environmental considerations; on the negative side, there is no body responsible for taking a lead in implementing a comprehensive energy strategy. Traditionally, environmental aspects in spatial planning have focused on green and water, objectives initiated by the Environmental Departments (Dienst Milieu) in municipalities. The Environment Department is a specialist on environmental matters, but it is not particularly interested in the costs or the residents. The Housing Departments have to integrate targets for the building sector, which has not been a traditional target group of an environmental policy.

In the case study, two main risks remained after the risk analysis: the risk that the rate of construction and installation (connections to the new energy infrastructure) would be lower than envisaged, and the risk that the price index of heat tariffs would cease to be linked to the price index of inflation. The energy provider and the energy supplier, who bear the financial risk, have no control over the building process. The separation between heat supply and heat distribution is also a risk: the network needs to be 'future proof' in case the plant closes down, so that the grid can be switched to a new low-carbon fuel.

When the plans for the district heating system in the Western Garden Cities were far enough advanced to be really open to discussion, they faced resistance from the residents, who feared higher energy bills and increased rents and disliked the idea of switching from gas to electricity for cooking. Most residents felt that having their own boiler was something far more tangible than district heating. Many residents of the Western Garden Cities were against demolition, which is one of the main renewal strategies, and some of them assumed that implementing the new energy infrastructure would be used as an argument for demolishing even more homes. The housing associations aimed to offset the residents' main concern (cooking with electricity) by giving them cookers of a higher than standard quality. The residents were regarded as being 'not interested in energy efficiency' at the beginning of the renewal process, but they were not given much information on the various different options either.

Efforts in the Western Garden Cities focused on the new energy grid rather than on improving the thermal performance of existing dwellings. In the first instance, it would be sensible to invest in refurbishing the existing stock to make it more energy efficient rather than a district heating system. If the homes were upgraded to passive energy homes, connecting them to a grid would not be so urgent. Lower energy 
consumption reduces the vulnerability to energy prices and increases the security of supply as well as enhancing comfort; it is also more cost-effective for occupants, as end-users pay three to five times as much for power as the price paid to utilities for corresponding new power delivered to the grid (Gether et al., 2005). As an alternative to district heating, solar energy-or in the future, micro-CHP-could be an interesting alternative in existing dwellings, as it does not require a new infrastructure, the responsibilities are divided to a lesser extent, there is less risk associated with the construction rate, and it does not involve temporary boilers and therefore delayed carbon savings.

\section{Policy recommendations}

Urban regeneration is high on the Dutch political agenda and has resulted in several investment programmes (Ministry of Spatial Planning, Housing and the Environment (MVROM), 1997, 1999). The approach adopted is a radical restructuring of the housing stock, adding more expensive dwellings for higher-income households, which entails demolishing, or in some cases renovating or selling, inexpensive, mostly rented, dwellings (Van Kempen and Priemus, 2002), also in the case studies. No official policy, however, has been defined for sustainable urban renewal. In order to facilitate coherent policy for urban renewal, the Dutch government has brought together a number of subsidy schemes in the Investment Budget for Urban Regeneration (ISV), a special-purpose grant scheme designed to improve the quality of the urban environment. Energy ambitions are reviewed in the ISV applications, but energy improvements are not required. In the first case study, the urban renewal policy of the Province of Zuid-Holland does not mention environmental objectives (Provincie Zuid-Holland, 2001). The Energy and Climate Policy Paper for 2000-10 (Provincie ZuidHolland, 2000) includes general energy-saving measures for the residential sector, but there are no sanctions for non-compliance.

As the building regulations mainly account for new construction (Sunikka, 2001; Beerepoot, 2002) and most energy subsidies were abolished in 2004 due to the proportion of free-riders, which was estimated to be as high as $60 \%$ (Egmond and Lulofs, 2005), the Dutch policy on energy efficiency in the housing stock has been implemented by voluntary pull measures (agreements, communication tools) and energy prices (Boon and Sunikka, 2004). The Energy Premium Regulation (EPR) scheme, including the Regulatory Energy Tax (REB) that increased energy bills by one-third, was introduced in 2000 to encourage households to invest in energy-efficiency measures. Energy price increases are needed to persuade users to adopt less polluting patterns of behaviour, given that enormous differences have been noted in the energy consumption of identical houses (Haas et al., 1998), but as seen in the first case study, energy prices would have to at least double to be effective. If prices increased $60 \%$ by 2012 , as anticipated in the Kyoto Protocol (Jansen et al., 2003), the NPV of renovation solutions 1 and 2 will be positive around 13 and 14 years, respectively, but the NPV for solutions 3 and 4 will still remain negative after 25 years. Furthermore, research shows that while half the population is aware of the REB in the Netherlands, only $2 \%$ take it into account in their electricity use (Van der Waals, 2001).

Due to the complexity of the obstacles identified in the case studies and the fact that extra costs and risks compared with a standard renovation are difficult to eliminate, extending the thermal requirements in the building regulations to existing housing seem necessary if energy efficiency is to be implemented in a large-scale way in urban renewal in the Netherlands. Legislation can also address the high-income households that do not have to react to price signals in their energy-consumption behaviour. Regulations cannot be imposed on the existing housing stock overnight, however, since most energy measures are not yet cost-efficient and not all households are in a position to respond to mandatory requirements, or the increased rents. Economic incentives are needed so that a mandatory policy does not cause problems for low-income households and create an ethical conflict with the right to housing, but due to the free-rider effect, subsidies should only be targeted for that part which would not be covered by the increased value of the property. As all decisions made at an earlier stage influence further choices, subsidies should be ensured at an early stage of the renewal process, otherwise there is a risk that energy-efficiency measures will not be carried out.

It should be considered that compliance with the introduction of thermal regulations for the existing housing stock is especially problematic, as not all renovations require notifying the building authorities, which on the other hand might not want to enforce the building regulations against private owners (Skifter Andersen and Leather, 1999). A property transaction, where an energy certificate will soon be required anyway according to the European Commission Energy Performance of Buildings Directive (EPBD) may be a good intervention point for controlling and improving the energy performance of a dwelling (European Commission, 2003).

Policy approaches based on the current voluntary approach in the Netherlands, and a more mandatory policy to legalize energy savings in the existing housing stock, both have advantages and disadvantages that are discussed in Table 5 in terms of communication instruments, negative and affirmative economic incentives, and building regulations. 
Table 5 Pros and cons of policy instruments for sustainable housing in relation to the two policy approaches

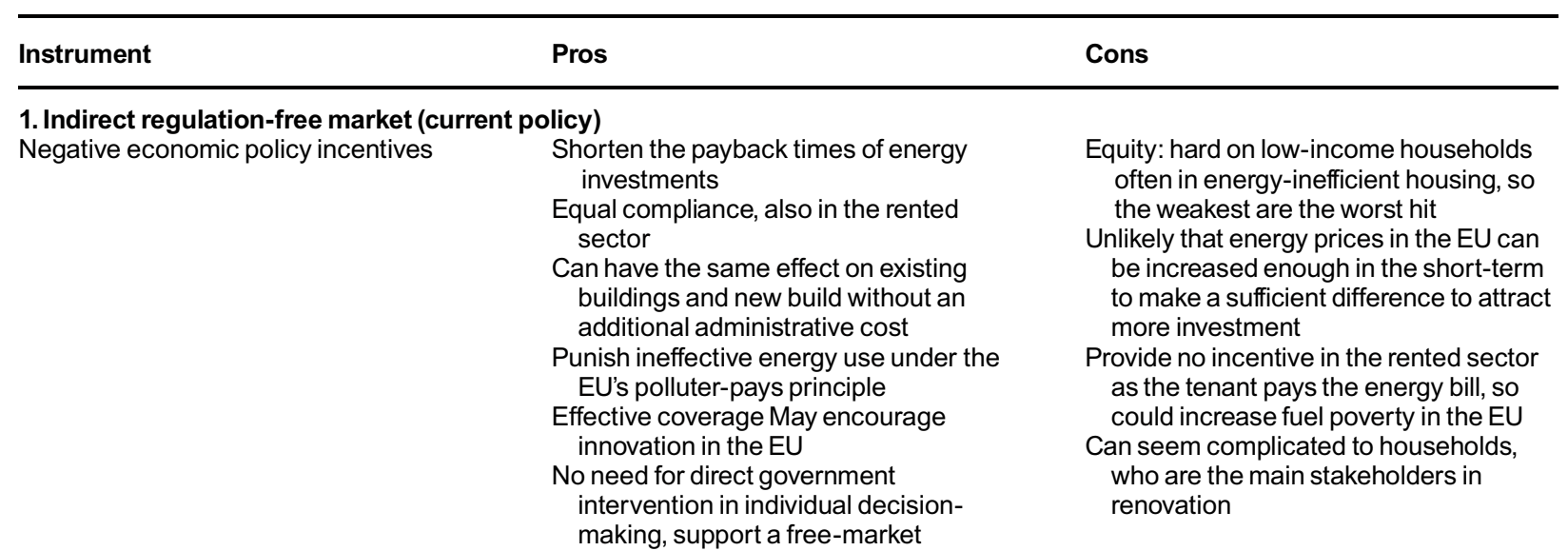

2. Direct regulation (recommended policy) Environmental requirements in building regulations

Positive economic incentives

\section{Supporting information (both strategies)} Communication tools

\section{Effective in forcing from attitudes to uncompromising action \\ Equal compliance, also in the rented sector \\ Shape the environment for usage-related energy-saving behaviour \\ Ensure minimum levels in the housing stock and the environment in the EU \\ Signal action from the national government}
Can help to increase the market share of improvements in energy efficiency in the EU
Shorten the payback times of energy investments
Trigger purchases and respond to present-day bias
Reward energy efficiency in the EU
Public acceptance and legitimacy
Support the market transformation strategy
Necessary to increase awareness, market demand and WTP for energy efficiency among all actors in the EU and to support compliance with the other policy instruments
Support the market transformation strategy

All households in the EU cannot respond because of economic considerations

No incentive to exceed the - often conservative - minimum, do not address all technical/economic feasibility aspects

Supervision is problematic if actions do not require one to notify the building authorities

Costs will be passed on to occupants Tend to lock in existing technologies

Price incentive needs to be high enough Not enough to make a project costeffective in most EU countries

Free-rider effect reported in the Netherlands, not a cost-effective allocation of resources for government

Stopping subsidies can have a bad effect

Do not provide strong market signals from the government and conflict with the EU's polluter-pays principle
Energy certificates: only an indication of energy performance, not self-policing; compliance with and adoption of measures need to be ensured through other policy measures in the EU
Risk of slow and imprecise impact if used alone

Note: EU, European Union.

Source: author.

There are some obstacles that need to be addressed at the level of actors instead of a government policy, e.g. the capture of benefits that is present in both case studies. Housing associations may feel that there are no benefits from making investments in energy efficiency if they are unable to raise rents. On the other hand, tenants may feel they are not responsible for undertaking investments in energy efficiency, especially if they expect to move out in the short- or medium-term. Therefore, the landlord should be able to guarantee the benefit of the investment for the tenant, e.g. if the tenant wants to implement energyefficient improvements on their own, they should be compensated for it when moving out. Different ownership models can also work to overcome this barrier. For example, the energy company could take on the leading role, taking over the existing system and replacing it with an energy-efficient alternative, which the tenant would lease from the energy company. 
Furthermore, as seen in the case studies, the decreasing role of the national government in urban renewal points the supervision and monitoring of the new legislation and the national policy at local authorities. Central and local government have less of a relation, while the importance between local authorities and other actors at the local level increases (Verhage, 2005). If responsibility is delegated to local governments, they must be guaranteed sufficient resources, funding and multidisciplinary knowledge to realize the tasks entrusted to them.

\section{Conclusions}

The paper reviewed the state of Dutch urban renewal from an environmental point of view and presented case studies that were undertaken in the context of a consortium research programme in the Netherlands. Using practical examples from two case studies, the paper examined obstacles to the implementation of energy efficiency improvements in existing housing and the use of sustainable energy sources in urban renewal, and it discussed the response of the current policy approach to overcome these obstacles, giving examples for the other countries that are still developing their policy approach.

The estimates of how much savings are possible in existing buildings in Europe vary, but a typical value is $30-40 \%$ improvement in energy efficiency (ECN/ RIVM, 1998; Slot et al., 1998; Sijanec Zavrl, 2001). The first case study illustrated that in a renovation, a reduction of this scale could be achieved with solution 2 involving the installation of new extra-high-performance windows and insulation. A household in an average dwelling could save $€ 272$ per year in their total energy costs, making the NPV of the investment positive after 20 years. However, even as the result of increased energy prices (Jansen et al., 2003), the NPV of solution 3, which added an HR107 boiler for space heating and a heat pump boiler for domestic hot water to solution 2 , and solution 4 , which looked at installing a solar boiler in addition to the previous measures, will remain negative even after 25 years, which is considered the point for the next intervention in the life cycle of the building.

This second case study looked at the Western Garden Cities in Amsterdam to see what barriers there are to replacing gas-fired heating with district heating provided by industrial waste heat, a project that could contribute an annual $\mathrm{CO}_{2}$ reduction of 34 million $\mathrm{kg}$ a year to the city of Amsterdam. The case study showed that careful consideration should be given to risk management and the preferences of residents when choosing a new energy source for a fuel switch, otherwise the scheme is likely to meet with obstacles to implementation similar to those found in the case study, especially if the renewal is implemented by a policy network. Uncertainties are caused by use of temporary boilers until the energy infrastructure is completed, because the final cost of the new energy infrastructure and the number of dwellings to be connected to the network are unknown and because responsibilities are divided into too many parties. The energy provider and energy supplier, who bear the financial risk, have no control over the building process, and due to the separation between heat supply and heat distribution, the grid has to be adaptable to be switched to a new low-carbon fuel. Not only has the role of housing associations become more commercial and focused on the risk and reward aspects, but also the liberalization of the energy market has produced commercial energy companies.

The case studies indicate that although there may be a more sophisticated understanding of different social, environmental and economic factors in urban renewal in the Netherlands, it does not mean the character or objectives of urban renewal would have been changed in practice, making it far too early to think about environmentally 'sustainable urban renewal'. Actually, most of the reasons why people did not save energy in buildings in the Netherlands in the 1980s are still familiar today: society in general wastes energy, feedback on energy consumption comes late and is of a general nature, some houses are energy-wasting and cannot be managed in an energy-conscious way, and there is an unwillingness to reduce comfort (Van Raaij and Verhallen, 1983). This raises the question whether government policy on energy efficiency in housing has been disoriented since the 1980s. The current, voluntary, energy-price-based policy in the Netherlands includes a risk that environmental improvements are only considered 'if there are no extra costs' or 'where possible' as identified in the interviews in the case studies (Boon and Sunikka, 2004). There are two main problem groups in a policy based on energy prices: high-income households that do not have to react to price signals; and low-income households that cannot afford to respond to them, and sometimes in the rental sector they are not even allowed to do so. Owing to costs, risks and a lack of leadership, it seems that in order for the policy to be effective, energy efficiency in the existing housing needs to be made more mandatory in urban renewal in the Netherlands. Introducing an energy standard by means of the energy certificate, in combination with economic measures for rewarding higher and punishing worse energy performance levels, seems an interesting approach that needs further research.

Many European countries are facing the challenge of urban renewal and pressure to reduce carbon emissions, and there is recognition of the limitations of traditional policy instruments. Every case study in urban renewal differs in terms of location, structure and market demand, and the small number of case studies 
presented here calls for caution when interpreting the results, but it was thought to be adequate to show the main obstacles. The European Union countries may be assumed to be those to which the resulting recommendations will be applied in the first instance.

\section{References}

Ashford, P. (1999) The Cost Implications of Energy Efficiency Measures in the Reduction of Carbon Dioxide Emissions from European Building Stock, EuroACE, Brussels.

Awano, H. (2005) Towards Sustainable Use of Buildings Stock: Final Synthesis Report, OECD, Paris.

Badescu, V. and Sicre, B. (2003) Renewable energy for passive house heating, Part I Building description. Energy and Buildings, 35, 1077-1084.

Baumann, H., Brunklaus, B., Gluch, P., Kadefors, A., Stenberg, A.-C., Thuvander, L. and Widman, J. (2002) Environmental drivers, management and results in Swedish building industry, in Proceedings of the Sustainable Building 2002 Conference, Oslo, Norway.

Beerepoot, M. (2002) Energy Regulations for New Building-In Search of Harmonisation in the European Union, Delft University Press, Delft.

Beerepoot, M. and Sunikka, M. (2005) The role of the EC energy certificate in improving sustainability of post-war housing areas, Environment and Planning B, 32, 21-31.

Boardman, B. (2004a) New directions for household energy efficiency: evidence from the UK. Energy Policy, 32(16), 19211933.

Boardman, B. (2004b) Starting on the road to sustainability. Building Research \& Information, 32(3), 264-268.

Boardman, B., Killip, G., Darby, S., Sinden, G., Jardine, C.N., Hinnells, M. and Palmer, J. (2005) 40\% House Report, University of Oxford, Oxford.

Boon, C. and Sunikka, M. (2004) Introduction to Sustainable Urban Renewal, $\mathrm{CO}_{2}$ Reduction and the Use of Performance Agreements: Experience from the Netherlands, Delft University Press, Delft.

Bureau Parkstad (2001) Richting Parkstad 2015, Ontwikkelingsplan voor de vernieuwing [Direction Parkstad 2015, Plan for the Urban Renewal], Bureau Parkstad, Amsterdam.

Bus, A.G. (2001) Duurzaam vernieuwing in naoorlogse wijken [Sustainable Renewal in Post-war Neighbourhoods], Geo Pers, Groningen. [English summary]

Clinch, J.P. and Healy, J.D. (1999) Domestic Energy Efficiency in Ireland: Correcting the Market Failure, Department of Environmental Studies/University College Dublin, Dublin.

Cohen, M.J. (2000) Ecological modernisation, environmental knowledge and national character: a preliminary analysis of the Netherlands, in A.P.J. Mol and D.A. Sonnenfeld (eds): Ecological Modernisation Around the World, Perspectives and Critical Debates, Frank Cass, London, pp. 77-108.

De Jonge, T. (2005) Cost Effectiveness of Sustainable Housing Investments, Delft University Press, Delft.

Duijvestein, K. (1998) Ecologisch bouwen [Ecological Construction], Studiegroep StadsOntwerp \& Milieu, Faculteit Bouwkunde, Delft.

European Commission (2003) Council Directive 2002/91/EC of 16 December 2002 on the energy performance of buildings. Official Journal of the European Communities, L1, 65-71.

European Commission (2005) Green Paper on Energy Efficiency, Doing More With Less, EC, Brussels.

ECN/RIVM (1998) Nationale Energie Verkenningen 19952020, Trends en thema's [National Energy Investigation 1995-2020, Trends and Themes], Energieonderzoek Centrum Nederland, Petten.

Egmond, C. and Lulofs, K. (2005) One size fits all? Policy instruments should fit the segments of target groups, in
Proceedings of the ECEEE 2005 Summer Study, European Council for an Energy Efficient Economy, Stockholm, pp. $735-744$.

Gether, H., Rognlien, S., Gether, J. and Nielsen, K. (2005) Sustainable energy shift in the building sector-feasible or infeasible?, in Proceedings of the ECEEE 2005 Summer Study, European Council for an Energy Efficient Economy, Stockholm, pp. 513-518.

Haas, R., Auer, H. and Biermayr, P. (1998) The impact of consumer behavior on residential energy demand for space heating. Energy and Buildings, 27(2), 195-205.

Hasegawa, T. (2002) Policies for Environmentally Sustainable Buildings. Report No. ENV/EPOC/WPNEP, (2002)5, OECD, Paris.

Hastings, S.R. (2004) Breaking the 'heating barrier'. Learning from the first houses without conventional heating. Energy and Buildings, 36, 373-380.

Hekkanen, M.T., Kauppinen, T. and Santalo, M. (1999) Lämmin lähiötalo, Betonielementtirakennuksen muodonmuutos tulevaisunden vuoksi [Warm Suburban Housing, Metamorphosis of Pre-fabricated Housing for the Future], Kiinteistöalan kustannus, Helsinki.

Jansen, Y., Brognaux, C. and Whitehead, J. (2003) Keeping the Lights On, Navigating Choices in European Power Generation, Boston Consulting Group, Boston, MA.

Jones, D.W, Bjornstad, D.J. and Greer, L.A. (2002) Energy Efficiency, Building Productivity and the Commercial Buildings Market, Oak Ridge National Laboratory, Oak Ridge, TN.

Klunder, G. (2005) Sustainable Solutions for Dutch Housing, Reducing the Environmental Impacts of New and Existing Houses, Delft University Press, Delft.

Kohler, N. and Hassler, U. (2002) The building stock as a research object. Building Research \& Information, 30(4), 226-236.

Kruythoff, H. and Haars, A. (2002) Herdifferentiatie van de woningvoorraad: inventarisatie meerjaren ontwikkelingsprogramma's G30 [Differentiation of the Housing Stock: Inventarisation of the Development Programme G30], Delft University Press, Delft.

Ligthart, F.A.T.M., Verhoog, S.M. and Gilijamse, W. (2000) Lange termijn energievisie op Parkstad, Amsterdam [Longterm Energy Vision on Parkstad, Amsterdam], ECN, Petten. [English summary]

Lowe, R. (2000) Defining and meeting the carbon constraints of the 21 st century. Building Research \& Information, 28(3), 159-175.

Ministry of Spatial Planning, Housing and the Environment (MVROM) (1997) Nota Stedelijke Vernieuwing (White Paper on Urban Renewal), MVROM, The Hague.

Ministry of Spatial Planning, Housing and the Environment (MVROM) (1999) Nota Wonen [Housing White Paper], MVROM, The Hague.

Murakami, S., Izumi, H., Yashiro, T., Ando, S. and Hasegawa, T. (2002) Sustainable Building and Policy Design, Institute of International Harmonisation for Building and Housing, Tokyo.

NOVEM (ed.) (2002) Operating Space for European Sustainable Building Policies. Report of the Pan European Conference of the Ministers of Housing Addressing Sustainable Building, Genvalle, Belgium, 27-28 June 2002, NOVEM, Utrecht.

Ouwehand, A. and Van Daalen, G. (2002) Dutch Housing Associations: A Model for Social Housing, Delft University Press, Delft.

Perman, R., Ma, Y., McGilvray, J. and Common, M. (2003) Natural Resource and Environmental Economics, Pearson Higher Education, London.

PRC (Bouwcentrum International) (2005) Sustainable Refurbishment of High-Rise Residential Buildings and Restructuring of Surrounding Areas in Europe. Report to the European Housing Ministers Conference, Prague, Czech Republic, 14-15 March 2005, PRC (Bouwcentrum International, Bodegraven). 
Priemus, H. (1999) Sustainable cities: how to realize an ecological breakthrough: a Dutch approach. International Planning Studies, 4(2), 213-236.

Priemus, H. (2002) Spatial-economic investment policy and urban regeneration in the Netherlands. Environment and Planning C, 20(5), 775-790.

Provincie Zuid-Holland (2000) Nota energie- en klimaatbeleid 2000-2010 [Energy and Climate Policy Paper 20002010], Provincie Zuid-Holland, The Hague.

Provincie Zuid-Holland (2001) Stedelijke transformatie in de wijk, De rol van de provincie bij de revitalisering van naoorlogse wijken [Urban Transformation in the Neighbourhood. The Role of the Province in the Revitalization of Post-war Housing Estates], Provincie Zuid-Holland, The Hague.

Sijanec Zavrl, M. (2001) Slovenia, government activities at all levels. Sustainable Building, 3(2001).

Sinden, G. (2005) Wave, wind, sun and tide is a powerful mix, The Guardian, 12 May (available at: http://www.guardian.co.uk/life/opinion/story/0,1481539,00.html).

Skifter Andersen, H. and Leather, P. (1999) Housing Renewal in Europe, Policy Press, Bristol.

Slot, B.J.M., Poel A. and Scholte, W.K. (1998) KWR'94-'96 Analyse energie en water [KWR'94-'96 Analysis of Energy and Water], Damen Consultants, Rotterdam/Arnhem.

Stichting Bouwresearch (1998a) Nationaal pakket duurzaam bouwen nieuwbouw [National Package for Sustainable Management], SBR, Rotterdam.

Stichting Bouwresearch (1998b) Nationaal pakket duurzaam bouwen beheer [National Package for Sustainable Management], SBR, Rotterdam.

Stichting Bouwresearch (2001) Attitude t.a.v. duurzaam bouwen en Nationaal Pakket Woningbouw-Utiliteitsbouw [Attitudes
Towards Sustainable Building and the National Package for Housing], SBR, Rotterdam.

Sunikka, M. (2001) Policies and Regulations for Sustainable Building. A Comparative Study of Five European Countries, Delft University Press, Delft.

Sunikka, M. and Boon, C. (2003) Environmental policies and efforts in social housing: the Netherlands. Building Research \& Information, 31(1), 1-12.

Van der Voordt, T. and Van Wegen, H. (2002) Programming of buildings, in T.M. de Jong and Van der Voort, D.J.M. (eds): Ways to Study and Research Urban, Architectural and Technical Design, Delft, Delft University Press.

Van der Waals, J.F.M. (2001) $\mathrm{CO}_{2}$ Reduction in Housing. Experiences in Building and Urban Renewal Projects in the Netherlands, Rozenberg, Amsterdam.

Van der Waals, J.F.M., Vermeulen, W.J.V. and Glasbergen, P. (2003) Carbon dioxide reduction in housing: experiences in urban renewal projects in the Netherlands. Environment and Planning C: Government and Policy, 21(3), 411-427.

Van Kempen, R. and Priemus, H. (2002) Revolution in social housing in the Netherlands: possible effects of new housing policies. Urban Studies, 39(2), 237-253.

Van Raaij, F. and Verhallen, T. (1983) A behavioral model of residential energy use. Journal of Economic Psychology, 3(1), 39-63.

Verhage, R. (2005) Renewing urban renewal in France, the UK and the Netherlands: introduction. Journal of Housing and the Built Environment, 20(3), 215-227.

W/E Adviseurs (2002) Energievisie Parkstad [Energy Vision Parkstad], Milieudienst Amsterdam, Amsterdam.

Yin, R.K. (1993) Applications of Case Study Research. Sage, Newbury Park, CA. 